\title{
Performance and bacterial community shifts during phosphogypsum biotransformation
}

Mónica Martins ${ }^{1,4}$, Ana Assunção ${ }^{1}$, André Neto ${ }^{1}$, Gonçalo Silva ${ }^{3}$, Haïtham Sghaier ${ }^{5,6}$, Maria Clara Costa ${ }^{1,2^{*}}$

${ }^{1}$ Centro de Ciências do Mar (CCMAR); ${ }^{2}$ Departamento de Química e Farmácia; Faculdade de Ciências e de Tecnologia, Universidade do Algarve, Campus de Gambelas, 8005-139 Faro, Portugal;

${ }^{3}$ Natural Resources Institute, University of Greenwich, Medway Campus, Central Avenue, Chatham Maritime, Kent, ME4 4TB, UK;

${ }^{4}$ Presently in Instituto de Tecnologia Química e Biológica (ITQB), Universidade Nova de Lisboa, Av. da República, 2780-157 Oeiras, Portugal.

${ }^{5}$ Laboratory "Energy and Matter for Development of Nuclear Sciences" (LR16CNSTN02), National Center for Nuclear Sciences and Technology (CNSTN), Sidi Thabet Technopark, 2020, Tunisia

${ }^{6}$ Associated with Laboratory "Biotechnology and Nuclear Technology" (LR16CNSTN01) \& Laboratory "Biotechnology and Bio-Geo Resources Valorization" (LR11ES31), Sidi Thabet Technopark, 2020, Tunisia

\section{Corresponding author:}

Maria Clara Costa*

Address: FCT- Universidade do Algarve, Ed. 8, Campus de Gambelas, 8005-139 Faro, Portugal

E-mail: mcorada@ualg.pt

Tel. +351289800900 ext. 7634

Fax: +351289818419 


\begin{abstract}
Phosphogypsum (PG) is an industrial waste composed mainly by sulphate, turning it a suitable sulphate source for sulphate-reducing bacteria (SRB). In the present work the capability of two SRB communities, one enriched from Portuguese PG (culture PG) and other from sludge from a wastewater treatment plant (culture WWT-1), to use sulphate from PG, was compared. In addition, the impact of this sulphate-rich waste in the microbial community was assessed. The highest efficiency in terms of sulphate reduction was observed with culture WWT-1. The bacterial composition of this culture was not significantly affected when sodium sulphate from the nutrient medium was replaced by PG as sulphate source. Next generation sequencing (NGS) showed that this community was phylogenetically diverse, composed by bacteria affiliated to Clostridium, Arcobacter and Sulfurospirillum genera and by SRB belonging to Desulfovibrio, Desulfomicrobium and Desulfobulbus genera. In contrast, the bacterial structure of the community enriched from PG was modified when sodium sulphate was replaced by PG as sulphate source. This culture, which showed the poorest performance in the use of sulphate from PG, was mainly composed by SRB related to Desulfosporosinus genus. The present work provides new information regarding the phylogenetic characterization of anaerobic bacterial communities with the ability to use PG as sulphate donor, thus contributing to improve the knowledge of microorganisms suitable to be used in PG bioremediation. Additionally, this paper demonstrates that an alternative to lactate and low-cost carbon source (wine wastes) can be used efficiently for that purpose.
\end{abstract}

Keywords: Biotransformation; Phosphogypsum; Phylogenetic characterization; Sulphate-reducing bacteria. 


\section{Introduction}

Mediterranean countries have by far the largest estimated reserves of phosphate rocks in the world (Jasinski 2011). Consequently, several industries of manufacture of phosphoric acid have been established in this region and will maintain their activity in the next decades. However, the production of phosphoric acid generates a major waste solid designated by phosphogypsum (PG), which is considered as a by-product of environmental concern (Tayibi et al. 2009). PG is an acidic waste due to residual sulfuric acid and due to the production method contains calcium sulphate dehydrate (gypsum) or calcium sulphate hemihydrate, silica, fluoride compounds and unreacted phosphate rocks (Binnemans et al. 2015). High levels of natural radionuclides and metals were also found in these wastes (Binnemans et al. 2015). It is estimated that around five tons of this waste is generated per ton of phosphoric acid produced (Enamorado et al., 2014), which exceeds the mass of product, and 100 to 280 $\times 10^{6}$ ton are produced worldwide (Cuadri et al. 2014; Tayibi et al. 2009).

Nowadays, only $15 \%$ of world PG production is recycled and used in constructional materials, agricultural fertilisers and in soil stabilisation amendments (Tayibi et al. 2009). The remaining PG is disposed as stock piles occupying a large land area near the industrial plants, which represent a potential chemical and radioactive pollution source (Binnemans et al. 2015; Tayibi et al. 2009). In Portugal, it is estimate that about 3.8 $\times 10^{6}$ tons of PG have been produced (Carvalho 1995), which was accumulated in large stockpiles in an industrial park. Therefore, the search of novel processes for PG treatment becomes highly important, not only environmentally but also economically.

Bioremediation process based on the activity of sulphate-reducing bacteria (SRB) are being considered an environmentally friendly and low cost alternative for the treatment of sulphate and metals-rich wastes (Jonhson and Hallberg 2005; Costa et al. 2009; Martins et al. 2011b). SRB are characterized by anaerobic respiration using sulphate as terminal electron acceptor for the degradation of organic compounds (Muyzer and Stams 2008) and since PG is mainly composed by sulphate, it makes it an attractive electron acceptor source for SRB. In fact, the potential of these microorganisms in PG bioremediation has been proved (Rzeczycka et al. 2004; Azabou et al. 2005; Wolicka and Kowalski 2006; Castillo et al. 2012).

Although PG biotransformation by SRB has been extensively studied (Rzeczycka et al. 2004; Azabou et al. 2005; Wolicka and Kowalski 2006; Castillo et al. 2012), none of these studies identified the bacteria involved in these processes, which is an important step towards the development of efficient processes aiming the treatment of PG. Thus, in the present work the ability of two anaerobic bacterial cultures to use the PG from three Mediterranean countries (Portugal, Spain and Tunisia) as sulphate source was investigated. Moreover, these communities were characterized by Next Generation Sequencing (NGS) and the effect of PG in the composition of the initial bacterial community was assessed.

\section{Material and methods}

\subsection{Physico-chemical characterization of phosphogypsum}

The PG used in the present study came from three Mediterranean zones: industrial park, called Quimiparque, located in the city of Barreiro, Portugal, PG pile next to Huelva town, Spain and from a fertiliser factory in Sfax city, Tunisia. The samples were collected approximately at $20 \mathrm{~cm}$ from the surface, transported to 
the laboratory and stored at $4{ }^{\circ} \mathrm{C}$. PG samples were submitted to a chemical digestion using aqua regia and dried afterwards. Then, the dried materials were dissolved in nitric acid $2 \%(\mathrm{v} / \mathrm{v})$ and filtered. The physico-chemical characterization of each PG is presented in Table 1.

\subsection{Microorganisms and growth conditions}

Two anaerobic cultures were used in this study: one enriched from a PG sample collected from a stockpile deposit located in Barreiro, Portugal (inoculum PG), and the other enriched from a sludge sample of anaerobic digestor of the municipal wastewater treatment plant of Lagos, southern Portugal, (inoculum WWT-1). The composition of the both bacterial communities was determined by restriction fragment length polymorphism analysis (RFLP) of 16S rRNA gene as described by Martins et al. (2013). The culture enriched from PG was composed by bacteria affiliated to Sedimentibacter (relative abundance of $47 \%$ ) and Clostridium (relative abundance of $31 \%$ ) genera, and SRB affiliated to Desulfotomaculum (relative abundance of $9 \%$ ) and Desulfosporosinus (relative abundance of $13 \%$ ) genera, while the culture denominated by WWT-1, which have more diversity, was composed by bacteria affiliated to Clostridium (relative abundance of $36 \%$ ) and Arcobacter (relative abundance of $16 \%$ ) genera, Sulfurospirillum barnesii (relative abundance of $12 \%$ ) and SRB affiliated to Desulfovibrio (relative abundance of $6 \%$ ) and Desulfomicrobium (relative abundance of $18 \%$ ) genera.

All cultures were enriched and subsequently grown in modified Postgate B medium containing (per liter of tap water): $0.5 \mathrm{~g} \mathrm{~K}_{3} \mathrm{PO}_{4} \cdot \mathrm{H}_{2} \mathrm{O}, 1 \mathrm{~g} \mathrm{NH} \mathrm{Cl}_{4}, 1 \mathrm{~g} \mathrm{CaCl}_{2} .2 \mathrm{H}_{2} \mathrm{O}, 1 \mathrm{~g}$ yeast extract, $0.1 \mathrm{~g}$ ascorbic acid, $0.5 \mathrm{~g} \mathrm{Na}_{2} \mathrm{SO}_{3}$, $75.4 \mu \mathrm{l}$ thioglycolic acid, $0.01 \mathrm{~g}$ resazurin, $0.5 \mathrm{~g} \mathrm{FeSO} 4.7 \mathrm{H}_{2} \mathrm{O}, 7.75 \mathrm{~g}$ sodium lactate, $2 \mathrm{~g} \mathrm{MgCl}_{2} .6 \mathrm{H}_{2} \mathrm{O}$ and $1 \mathrm{~g}$ $\mathrm{Na}_{2} \mathrm{SO}_{4}$. Bacterial growth was carried out at room temperature $\left( \pm 21^{\circ} \mathrm{C}\right)$ in $120 \mathrm{ml}$ serum bottles with a working volume of $100 \mathrm{~mL}$ and $\mathrm{N}_{2}$ as gas headspace. The bottles were sealed with butyl rubber stoppers and aluminum crimp seals.

\subsection{Assays of anaerobic PG biotransformation}

The assays were performed in batch under anaerobic conditions at room temperature $\left(21 \pm 1^{\circ} \mathrm{C}\right)$ using $120 \mathrm{ml}$ glass serum bottles with a working volume of $90 \mathrm{ml}$. All studies were done using Postgate B medium described before in the section 2.2 but without sulphate. The medium was autoclaved at $120^{\circ} \mathrm{C}$ during 20 min and distributed in sterile serum bottles containing PG also sterile (by autoclaving). The medium was purged with nitrogen gas during their cooling. After that, the bottles were sealed with butyl rubber stoppers and aluminum crimp seals. All experiments were performed in duplicate using $10 \%(\mathrm{v} / \mathrm{v})$ of inoculum. Bacterial cells were harvested by centrifugation at $4000 \mathrm{rpm}$ for $10 \mathrm{~min}$, washed with growth medium and transferred to the bottles containing the medium to be tested.

\subsubsection{Assessment of PG as sulphate source for anaerobic bacterial growth}

In order to evaluate the ability of the bacterial cultures to use the sulphate present in PG samples as electron acceptor, the sodium sulphate present in the Postgate B medium was replaced by PG at concentrations of 5 and $10 \mathrm{~g} \mathrm{l}^{-1}$. PG from the three Mediterranean zones (Portugal, Spain and Tunisia) was tested. For each experiment an abiotic control was carried out in parallel. The abiotic controls were prepared in the same way as the biotic tests, but without inoculum addition. 


\subsubsection{Effect of carbon source in the utilization of $P G$ as sulphate source}

The ability to use other carbon sources beside lactate in the biotransformation of PG was also investigated. For this purpose, lactate was replaced by ethanol and by wine waste from winery industry. In this study $6 \mathrm{~g} \mathrm{l}^{-1}$ of carbon source was used. In the assay with wine wastes the medium was supplemented with 112 $\mathrm{ml} \mathrm{l}^{-1}$ of wine waste and $20 \mathrm{~g} \mathrm{l}^{-1}$ of calcite tailing to maintain the $\mathrm{pH}$ of the medium within values suitable for SRB growth and activity ( $\mathrm{pH}$ 7.4) (Martins et al. 2009b). The waste from the winery industry was collected prior to the bottling stage and High-Performance Liquid Chromatography measurements indicated that it contains 53.5 $\mathrm{g} \mathrm{l}^{-1}$ of ethanol (Costa et al. 2009). Its composition is similar to that of diluted red wine and the $\mathrm{pH}$ was $3.8 \pm 0.1$. The calcite tailing used as a neutralizing and buffer material to guarantee a suitable $\mathrm{pH}$ of the medium with wine wastes is a residue from a marble stone cutting and polishing industry. This material was mainly composed of magnesium calcite ( $89 \%)$, quartz ( $11 \%)$ and traces of illite mineral (Barros et al. 2009).

\subsection{Structure of microbial communities}

The characterization of the microbial communities with ability to use PG as sulphate donor was carried out by NGS. Total genomic DNA was extracted after harvesting cells by centrifugation at $4000 \mathrm{rpm}$ for $10 \mathrm{~min}$ using the methodology previously described by Martins et al. (2009a). NGS was carried out by DNASense ApS company (Aalborg, Denmark) through sequencing of 16S rRNA amplicons using V1-3 specific primers (27F AGAGTTTGATCCTGGCTCAG and 534R ATTACCGCGGCTGCTGG) and MiSeq (Illumina, USA). The procedure for bacterial 16S rRNA amplicon sequencing targeting the V1-3 variable regions is based on Caporaso et al. (2012). The PCR reaction contained dNTPs (400nM of each), $\mathrm{MgSO}_{4}(1.5 \mathrm{mM})$, Platinum ${ }^{\circledR}$ Taq DNA polymerase HF (2mU), 1X Platinum ${ }^{\circledR}$ High Fidelity buffer (Thermo Fisher Scientific, USA), and barcoded library adaptors $(400 \mathrm{nM})$ containing V1-3 specific primers: 27F AGAGTTTGATCCTGGCTCAG and 534R ATTACCGCGGCTGCTGG. The PCR conditions used were an initial denaturation at $95{ }^{\circ} \mathrm{C}$ for $2 \mathrm{~min}, 30$ cycles of $95{ }^{\circ} \mathrm{C}$ for $20 \mathrm{~s}, 56{ }^{\circ} \mathrm{C}$ for $30 \mathrm{~s}, 72{ }^{\circ} \mathrm{C}$ for $60 \mathrm{~s}$ and final elongation at $72{ }^{\circ} \mathrm{C}$ for $5 \mathrm{~min}$. Taxonomy was assigned using the RDP classifier as implemented in the parallel assign taxonomy rdp.py script in QIIME using the Greengenes database taxonomy v.13.8. The results were analyzed through the Rstudio IDE using the ampvis package v.1.9.1. The sequencing data generated in the present investigation was archived in NCBI Sequence Read Archive (SRA) database (http://www.ncbi.nlm.nih.gov/sra) with the accession SRP074193 and submitted under BioProject ID: PRJNA319624.

\subsection{Analytical Methods}

Periodically, $5 \mathrm{ml}$ of liquid samples were collected using a syringe and centrifuged at $4000 \mathrm{rpm}$ for 5 min. Redox potential and $\mathrm{pH}$ were determined using a $\mathrm{pH} / \mathrm{E}$ Meter (GLP 21, Crison). Sulphate concentration was quantified by UV/visible spectrophotometry (Hach-Lange DR2800 spectrometer) using the method of SulfaVer®4 (Hach-Lange, Germany). The analysis of $\mathrm{Na}$ and $\mathrm{K}$ in the solutions resulting from the chemical digestion of the different PG sources was performed by Flame Emission Photometry (Jenway, PFP7), while the metals were determined by Flame Atomic Absorption Spectroscopy (FAAS, Varian, Spectra AA-20) using an air-acetylene flame and the resonance wavelength lines of those elements accordingly with manufacturing instructions. 


\section{Results and discussion}

\subsection{Phosphogypsum composition}

The physico-chemical characterization of the PGs used in this study is shown in Table 1. The three PGs have similar composition and only a few parameters are distinct, like $\mathrm{pH}$ that is more acidic in the PG sample from Tunisia ( $\mathrm{pH}$ 2.85) than the PG from Portugal and Spain ( $\mathrm{pH} 5.43$ and 5.25, respectively). The Pb content in the PG from Portugal (5 ppm) is higher than in the other PGs where the Pb values were below to detection limit of AAS. Otherwise, the concentration of zinc in the PG from Tunisia is very high, reaching the value of 157 $\mathrm{ppm}$. The PG from Spain and from Portugal contains 30 and $6 \mathrm{ppm}$ of zinc, respectively. The concentration of Fe and $\mathrm{Cu}$ is higher in the PG from Spain and Tunisia comparatively with the Portuguese PG. The concentration of radionuclides in PG was not determined in this study. However, these wastes were considered as a low-level radioactive material due the presence of uranium (US EPA, 1999).

\subsection{Biotransformation of PG}

The profiles of sulphate consumption of the two bacterial cultures used in the present work when grown in Postgate B medium (containing sodium sulphate as sulphate source) are presented in Fig 1. After 7 days, $97 \%$ of sulphate was consumed by the community WWT- 1 while $46 \%$ was consumed by the PG inoculum after 14 days. The excellent performance in terms of sulphate reduction together with the physiologic characteristics of the bacterial consortium enriched from sludge of WWTP make it a good candidate for bioremediation of wastes containing sulphate and metals, like PG. However, the community enriched from the PG sample (PG inoculum) is probably better adapted to the characteristics of PG, since it was precisely enriched from these wastes. Thus, in the present work the capability of PG inoculum to use the sulphate present in PG was compared with ability of the bacterial community not enriched from these wastes.

\subsubsection{Biotransformation of Portuguese PG}

The sulphate reduction profile of the two bacterial consortia (PG and WWT-1) is showed in Figure 2. In the non-inoculated assays, leaching of sulphate from PG to the medium was observed during the experiment reaching the concentrations of 2.6 and $3.2 \mathrm{~g} \mathrm{l}^{-1}$ from 5 and $10 \mathrm{~g} \mathrm{l}^{-1}$ of PG, respectively, after 27 days. These values correspond to $100 \%$ and $61 \%$ of the maximum sulphate that is possible to be leached from 5 and $10 \mathrm{~g} \mathrm{l}^{-1}$, respectively.

Although the two enriched consortia were able to use sulphate from Portuguese PG, they present a different sulphate concentration profile. PG culture, which was enriched from a PG sample and that consequently could have the advantage of being better adapted to the PG environment, showed the lowest efficiency in terms of sulphate reduction. The sulphate concentration was maintained at $1500 \mathrm{~g} \mathrm{l}^{-1}$ and $1800 \mathrm{mg} \mathrm{l}^{-1}$ when 5 and $10 \mathrm{~g}$ $1^{-1}$ of PG were used, respectively (Fig $2 a$ and b). On the other hand, the culture enriched from the sample of the WWTP showed an excellent performance in the utilization of the sulphate leached from PG. When $5 \mathrm{~g} \mathrm{l}^{-1}$ of PG was inoculated with consortium WWT-1, the concentration of sulphate decreased during the study, reaching the value of $78 \mathrm{mg} \mathrm{l}^{-1}$ in the end of the experiment (Fig 2a). The culture WWT-1 also showed ability to use the 
sulphate leached from $10 \mathrm{~g} \mathrm{l}^{-1}$ of PG. In this case, the concentration of sulphate was maintained at $1000 \mathrm{mg} \mathrm{l}^{-1}$ during all experiment (Fig 2b). Along the experiments the $\mathrm{pH}$ decreased from 7.4 to $6.9 \pm 0.2$ in the presence of bacteria and from $7.0 \pm 0.1$ to $6.6 \pm 0.2$ in the assays of PG leaching without bacteria (Fig. 2c and d). The Eh decreased substantially in the presence of bacteria, as a result of the SRB activity, achieving values of $-370 \mathrm{mV}$ (from -110mV). In the negative controls (assays of leaching) the Eh increased slightly due to leaching of sulphate, salts and ionic forms, reaching a value of $-60 \mathrm{mV}$ (Fig. 2e and f).

Taking into account the amount of sulphate leached in the absence of bacteria $\left(2.6\right.$ and $3.2 \mathrm{~g} \mathrm{l}^{-1}$ from 5 and $10 \mathrm{~g} \mathrm{l}^{-1}$ ) and the maximum sulphate that can be leached from PG (2.6 and $5.3 \mathrm{~g} \mathrm{l}^{-1}$ from 5 and $\left.10 \mathrm{~g} \mathrm{l}^{-1}\right)$, the community enriched from WWTP showed an efficient utilisation of the sulphate present in the Portuguese PG. Considering only the sulphate that was leached, 97 and $70 \%$ of sulphate leached from the solutions containing 5 and $10 \mathrm{~g} \mathrm{l}^{-1}$ of PG, respectively, was used by consortium WWT-1, while consortium PG showed ability to use 43 $\%$ of sulphate leached from both PG concentrations. Wolicka and Borkowski (2009) reported a consumption of $58 \%$ of sulphate leached when the initial PG concentration was $6 \mathrm{~g} \mathrm{l}^{-1}$ and the carbon source was lactate, which are inferior to that observed by culture WWT-1. Moreover, the values of sulphate utilization from PG by culture WWT-1 were higher than those reported by Castillo et al. (2012), demonstrating that this community can be a potential candidate to be used in processes involving PG biotransformation.

Since the community WWT-1 showed the best performances in the utilization of sulphate from PG, it was selected for the following experiments.

\subsubsection{Biotransformation of PG from Spain and Tunisia}

The ability of consortium WWT-1 to use sulphate from PG of other Mediterranean countries (Spain and Tunisia) was also investigated (Fig. 3). It was observed that in absence of bacteria 1.3 and $2.9 \mathrm{~g} \mathrm{l}^{-1}$ of sulphate was leached from 5 and $10 \mathrm{~g} \mathrm{l}^{-1}$ of Spanish PG, respectively, and 1.9 and $2.7 \mathrm{~g} \mathrm{l}^{-1}$ of sulphate was leached from 5 and $10 \mathrm{~g} \mathrm{l}^{-1}$ of Tunisian PG, respectively. In the assay with $5 \mathrm{~g} \mathrm{l}^{-1} \mathrm{PG}$ (Fig. 3a and 3c) an efficient utilization of the sulphate present in PG by culture WWT-1 was observed independently of the PG source. In fact, the values of sulphate were maintained below $50 \mathrm{mg} \mathrm{l}^{-1}$ until the end of the experiment, which are similar to those observed with Portuguese PG. When the PG concentration was increased to $10 \mathrm{~g}^{-1}$ (Fig. 3b and 3d), it was observed that after the adaptation period of 14 days, the WWT-1 community was able to use efficiently the leached sulphate, maintaining the concentration of sulphate below 700 and $500 \mathrm{mg}^{-1}$ in the presence of Spanish and Tunisian PG, respectively. This adaptation phase was longer than that observed in the presence of PG from Portugal (7 days), probably due to the characteristics of the PG source. The metals and radionuclides composition of PG is variable and depends on their content in the phosphate rock and the production process of PG (Binnemans et al. 2015). The content of $\mathrm{Fe}, \mathrm{Cu}$ and $\mathrm{Zn}$ in PG from Spain and Tunisia is higher than in the PG from Portugal (Table 1), which may justify the shorter adaptation period when this last PG was used.

\subsubsection{Biotransformation of PG using different carbon sources}

Taking into account that PG biotransformation cannot be accomplished without the addition of an external carbon source, the application of a low cost organic is essential for the economic viability of the biotransformation process. According to this perspective, PG biotransformation by the community WWT-1 using ethanol and wine wastes as carbon source was evaluated (Fig. 4). Experiments without the addition of an 
external carbon source were not performed because previous studies demonstrated that, although PG contains some organic matter (Rutherford et al. 1994), sulphate reduction from PG is impossible without supplementing the medium with a carbon source (Azabou et al. 2005). In the non-inoculated studies, leaching of sulphate from PG to the medium was observed, reaching the concentration of 2.6 in the end of the experiment which corresponds to $100 \%$ of the maximum sulphate that is possible to be leached. The performance of sulphate utilization by consortium WWT-1 increased during the incubation time for all the carbon sources. At the end of the experiment this consortium was able to use 97,81 and $93 \%$ of the leached sulphate using lactate, ethanol and wine wastes as carbon sources, respectively.

Wine wastes was previously reported as a good substrate for the activity of SRB in the treatment of acid mine drainage (Costa et al. 2009; Martins et al. 2009b; Martins et al. 2011a) and this study demonstrated that it can also be suitable for the biotransformation of PG by SRB communities. The application of low cost organic substrates for PG biotransformation by SRB has been investigated (Wolicka and Borkowski 2009; Castillo et al. 2012). Wolicka and Borkowski (2009) and showed that effective biotransformation of PG was possible with the simultaneous biotransformation of whey. Castillo et al. (2012) proved that horse manure can also be a suitable organic substrate for SRB activity, since $61 \%$ of sulphate was removed using this substrate. However, this efficiency is lower than that observed in the present work with wine wastes, demonstrating that this food waste can be a potential low cost substrate for the biotransformation of PG using SRB.

\subsection{Evaluation of PG impact on the bacterial communities structure}

PG biotransformation by sulphate-reducing bacteria communities has been extensively studied and their potential in PG bioremediation was proved (Azabou et al. 2005; Wolicka and Borkowski 2009; Castillo et al. 2012). However, the characterization of the bacterial communities involved in these processes was rarely investigated. In the present work two anaerobic bacterial communities with ability to use PG as sulphate source were characterized. Beside the knowledge about the bacteria involved in the PG biotransformation, this study allowed to evaluate, for the first time, the impact of PG in the initial structure of the bacterial communities.

The composition of the two bacterial communities (PG and WWT-1) in the end of the study of biotransformation of $10 \mathrm{~g} \mathrm{l}^{-1}$ of Portuguese PG is showed in Figure 5. The community PG was mainly composed by bacteria affiliated to Desulfosporosinus genus and Clostridiaceae family. Although, these phylogenetic groups were detected in the bacterial community PG before the studies of PG biotransformation, other groups were also present in the initial community namely bacteria affiliated to Sedimentibacter and Desultotomaculum genera. These results indicate that the presence of PG affected the structure of the bacterial community privileging the growth of some bacteria (in this case bacteria belong to Desulfosporosinus genus) and inhibiting other like Sedimentibacter and Desultotomaculum genera (Fig. 6). Desulfosporosinus spp. are endosporeforming sulphate reducers, which have been detected in several environments contaminated with metals, such as methylmercury-contaminated mine tailings (Winch et al. 2009) and environments with acidic pH (SánchezAndrea et al. 2015). In this work we demonstrated that these bacteria can also be found in PG. Moreover, this bacterial group are probably responsible for the reduction of sulphate by community PG.

The initial community WWT-1 showed to have more diversity than the PG culture, being composed by bacteria affiliated to Clostridium and Arcobacter genera, SRB affiliated to Desulfovibrio and Desulfomicrobium genera and Sulfurospirillum barnesii. However, in contrast to the PG culture the bacterial composition of WWT- 
1 after the exposition to PG is not very different to the initial (Fig. 5 and Fig. 6). The community was mainly composed by bacteria belonging to Clostridium and Arcobacter genera and bacteria affiliated to Porphyromonadaceae family and to Clostridiales order. Concerning the group of SRB, this community was composed by bacteria affiliated to Desulfovibrio and Desulfomicrobium genera (already detected in the initial community) and by bacteria affiliated to Desulfobulbus sp. Bacteria affiliated to the genus Desulfobulbus spp. has been involved in mercury methylation and the in treatment of acid mine drainage (Martins et al. 2009a; Shao et al. 2012; Deng et al. 2016). Desulfovibrio spp. and Desulfomicrobium spp. are Gram negative and non-spore forming sulphate reducers that have been used for bioremediation of several sulphate-containing effluents (Martins et al. 2009a; Boothman et al. 2006). Moreover, species of Desulfomicrobium and Desulfovibrio have been isolated from PG (Azabou et al. 2007, Thabet et al. 2007).

Phylogenetic diversity of culture WWWT-1 can be the reason of the great performance in the utilization of PG as sulphate source and the reason why the microbial community structure was not significantly affected by the alteration of the sulphate source.

\section{Conclusion}

The objective of the present study was to provide knowledge about the phylogeny of the bacterial community involved in biotransformation of PG, which is an issue poor explored. Although the possibility of using SRB naturally occurring in PG for it biotransformation has been shown elsewhere, the present work demonstrates that the use of SRB enriched from a different source presents higher potential for PG biotransformation, since a great efficiency in terms of sulphate reduction was observed by a culture enriched from a WWTP. In addition, it was demonstrated that a low-cost carbon source (wine wastes) was efficiently used. Next generation sequencing showed that this community was composed by SRB belonging to Desulfovibrio, Desulfomicrobium and Desulfobulbus genera. On the other hand, the culture enriched from Portuguese PG, which showed the poorest performance in the use of sulphate from PG, was mainly composed by SRB related to Desulfosporosinus genus. The performance of the bacterial community enriched from the WWTP makes it a good candidate for PG bioremediation.

\section{Aknowlegments}

Funding by Fundação para a Ciência e a Tecnologia (FCT) through the Joint-Research Protocol Tunisia-Portugal. The authors also want to acknowledge Quimiparque and the Groupe Chimique Tunisien (GCT) for providing PG samples of Portugal and Tunisia, respectively. The authors also want to acknowledge Jorge Carlier to support in the molecular biology techniques.

\section{References}

Azabou S, Mechichi T, Patel BKC, Sayadi S (2007) Isolation and characterization of a mesophilic heavy-metalstolerant sulphate reducing bacterium Desulfomicrobium $\mathrm{sp}$. from an enrichment culture using phosphogypsum as a sulphate source. J Hazard Mater 140:264-270. doi: 10.1016/j.jhazmat.2006.07.073 
Azabou S, Mechichi T, Sayadi S (2005) Sulphate reduction from phosphogypsum using a mixed culture of sulphate reducing bacteria. Int Biodeter Biodegr 56:236-242. doi: 10.1016/j.ibiod.2005.09.003

Barros RJ, Jesus C, Martins M, Costa MC (2009) Marble stone processing powder residue as chemical adjuvant for the biologic treatment of acid mine drainage. Process Biochem 44:477-480. doi: 10.1016/j.procbio.2008.12.013

Binnemans K, Jones PT, Blanpain B, Gerven TV, Pontikes Y (2015) Towards zero-waste valorisation of rareearth-containing industrial process residues: a critical review. J Clean Prod 99:17-38. doi:10.1016/j.jclepro.2015.02.089

Boothman C, Hockin S, Holmes DE, Gadd GM, Lloyd JR (2006) Molecular analysis of a sulphate-reducing consortium used to treat metal-containing effluents. Biometals 19:601-609. doi: 10.1007/s10534-006-0006-Z

Caporaso JG, Lauber CL, Walters WA, Berg-Lyons D, Huntley J, Fierer N, Owens SM, Betley J, Fraser L, Bauer M, Gormley N, Gilbert JA, Smith G, Knight R (2012) Ultra-high throughput microbial community analysis on the Illumina HiSeq and MiSeq platforms. The ISME journal 6:1621-1624. doi: 10.1038/ismej.2012.8

Carvalho FP (1995) 210Pb and 210Po in sediments and suspended matter in the Tagus estuary, Portugal. Local enhancement of natural levels by wastes from phosphate ore processing industry. Sci Total Environ 159:201214. doi: 10.1016/0048-9697(95)04332-U

Castillo J, Pérez-López R, Sarmiento AM, Nieto JM (2012) Evaluation of organic substrates to enhance the sulphate-reducing activity in phosphogypsum. Sci Total Environ 439:106-113. doi: 10.1016/j.scitotenv.2012.09.035

Costa MC, Santos ES, Barros RJ, Pires C, Martins M (2009) Wine wastes as carbon source for biological treatment of acid mine drainage. Chemosphere 75:831-836. doi: 10.1016/j.chemosphere.2008.12.062

Cuadri AA, Navarroa FJ, García-Morales M, Bolivar JP (2014) Valorization of phosphogypsum waste as asphaltic bitumen modifier. J Hazard Mater 279:11-16. doi:10.1016/j.jhazmat.2014.06.058

Deng D, Weidhaas JL, Lin L-S (2016) Kinetics and microbial ecology of batch sulfidogenic bioreactors for cotreatment of municipal wastewater and acid mine drainage. J Hazard Mater 305:200-208. doi: 10.1016/j.jhazmat.2015.11.041

Enamorado, S, Abril JM, Delgado A, Más JL, Polvillo O, Quintero JM (2014) Implications for food safety of the uptake by tomato of 25 trace-elements from a phosphogypsum amended soil from SW Spain. J Hazard Mater 266:122-131. doi: 10.1016/j.jhazmat.2013.12.019 
Jasinski SM (2011) Phosphate Rock, Mineral Commodity Summaries. In U.S. Geological Survey.

Johnson DB, Hallberg KB (2005) Biogeochemistry of the compost bioreactor components of a composite AMD passive remediation system. Sci Total Environ 338:81-93. doi: 10.1016/j.scitotenv.2004.09.008

Martins M, Faleiro ML, Barros RJ, Veríssimo AR, Barreiros MA, Costa MC (2009a) Characterization and activity studies of highly heavy metal resistant sulphate-reducing bacteria to be used in acid mine drainage treatment. J Hazard Mater 166:706-713. doi: 10.1016/j.jhazmat.2008.11.088

Martins M, Faleiro ML, Barros RJ, Veríssimo AR, Costa MC (2009b) Biological sulphate reduction using food industry wastes as carbon sources. Biodegradation 20:559-567. doi: 10.1007/s10532-008-9245-8

Martins M, Faleiro ML, Silva G, Chaves S, Tenreiro R, Costa MC (2011a) Dynamics of bacterial community in up-flow anaerobic packed bed system for acid mine drainage treatment using wine wastes as carbon source. Int Biodeter Biodegr 65:78-84. (doi: 10.1016/j.ibiod.2010.09.005)

Martins M, Santos ES, Faleiro ML, Silva G, Chaves S, Tenreiro R, Barros RJ, Barreiros A, Costa MC (2011b) Performance and bacterial community shifts during bioremediation of acid mine drainage from two Portuguese mines. Int Biodeter Biodegr 65:972-981. doi: 10.1016/j.ibiod.2011.07.006

Martins, M., Assunção, A., Martins, H., Matos, A.P., Costa, M.C., 2013. Palladium recovery as nanoparticles by an anaerobic bacterial community. Journal of Chemical Technology and Biotechnology 88, 2039-2045. (doi: $10.1002 /$ jctb.4064)

Muyzer G, Stams AJM (2008) The ecology and biotechnology of sulphate-reducing bacteria. Nat Rev Microbiol 6:441-454. doi: 10.1038/nrmicro1892

Rutherford PM, Dudas MJ, Samek RA (1994) Environmental impacts of phosphogypsum. Sci Total Environ 149:1-38. doi: 10.1016/0048-9697(94)90002-7

Rzeczycka M, Suszek A, Błaszczyk M (2004) Biotransformation of phosphogypsum by sulphate-reducing bacteria in media containing different zinc salts. Pol J Environ Stud 13:209-217.

Sànchez-Andrea I, Stams AJM, Hedrich S, Nancucheo I, Johnson DB (2015) Desulfosporosinus acididurans sp. nov.: an acidophilic sulfate-reducing bacterium isolated from acidic sediments. Extremophiles 19:3947. doi: 10.1007/s00792-014-0701-6 
Shao D, Kang Y, Wu s, Wong MH (2012) Effects of sulfate reducing bacteria and sulfate concentration on mercury methylation in freshwater sediments. Sci Total Environ 424:331-336. doi:10.1016/j.scitotenv.2011.09.042

Tayibi H, Choura M, López FA, Alguacil FJ, López-Delgado A (2009) Environmental impact and management of phosphogypsum. J Environ Manage 90:2377-2386. doi: 10.1016/j.jenvman.2009.03.007

Thabet O, Fardeau M, Suarez-Nuñez C, Hamdi M, Thomas P, Ollivier B, Alazard D (2007) Desulfovibrio marinus sp. nov., a moderately halophilic sulphate-reducing bacterium isolated from marine sediments in Tunisia, Int J Syst Evol Micr 57:2167-2170. doi: 10.1099/ijs.0.64790-0

US EPA (1999) United States Environmental Protection Agency. Background report on fertilizer use, contaminants and regulations. Office of pollution, Prevention and toxics 747-R-93-003, Washington D. C.

Winch S, Mills HJ, Kostka JE, Fortin D, Lean DR (2009) Identification of sulfate-reducing bacteria in methylmercury-contaminated mine tailings by analysis of SSU rRNA genes. FEMS Microbiol Ecol 68:94-107. doi: 10.1111/j.1574-6941.2009.00658.x.

Wolicka D, Borkowski A (2009) Phosphogypsum biotransformation in cultures of sulphate reducing bacteria in whey. Int Biodeter Biodegr 63:322-327. doi: 10.1016/j.ibiod.2008.09.011

Wolicka D, Kowalski W (2006) Biotransformation of phosphogypsum on distillery decoctions (preliminary results). Pol J Microbiol 55:147-151. 
Table 1- Physico-chemical characterization of phosphogypsum from the three Mediterranean zones: Portugal, Spain and Tunisia.

\begin{tabular}{lccc}
\hline Composition & Portugal & Spain & Tunisia \\
\hline $\mathrm{pH}$ & 5.43 & 5.25 & 2.85 \\
$\mathrm{Eh}(\mathrm{mV})$ & +142 & +213 & +228 \\
$\mathrm{Dry}-$ weight $(\%)$ & 87.8 & 85.0 & 86.1 \\
$\mathrm{SO}_{4}^{2-}(\%)$ & 52.5 & 46.6 & 55.4 \\
$\mathrm{Ca}(\%)$ & 24.4 & 25.1 & 11.1 \\
$\mathrm{~K}(\%)$ & 0.01 & 0.04 & 0.03 \\
$\mathrm{Na}(\%)$ & 0.12 & 0.33 & 0.50 \\
$\mathrm{Fe}(\%)$ & 0.01 & 0.07 & 0.06 \\
$\mathrm{Mg}(\%)$ & $6 \times 10^{-6^{* * *}}$ & 0.01 & 0.05 \\
$\mathrm{Cu}(\mathrm{ppm})$ & 8 & 20 & 20 \\
$\mathrm{Zn}(\mathrm{ppm})$ & 6 & 30 & 157 \\
$\mathrm{~Pb}(\mathrm{ppm})$ & 5 & $2 \times 10^{-4^{* * *}}$ & $<2 \times 10^{-4^{* * *}}$ \\
$\mathrm{Co}(\mathrm{ppm})$ & 4 & 2 & 0.23
\end{tabular}

*The results presented are the media of two samples and the composition is expressed in $\%(\mathrm{w} / \mathrm{w})$.

** These values correspond to the detection limits of AAS. 


\section{Figure captions}

Fig. 1 Sulphate reduction profile of the two enriched cultures: one enriched from Portuguese phosphogypsum (PG) and the other from sludge of a WWTP (WWT-1). Data are the average of duplicate incubations and error bars indicate the standard deviations of the average values

Fig. 2 Profiles of sulphate (a and b), pH (c and d) and Eh (e and f) during incubation of Portuguese phosphogypsum with the two bacterial communities: enriched from Portuguese phosphogypsum (PG) and from sludge of WWTP (WWT-1). Two different concentrations of phosphogypsum were used: $5 \mathrm{~g} \mathrm{l}^{-1}$ (a, c and e) and $10 \mathrm{~g} \mathrm{l}^{-1}$ (b, d and f). Data are the average of duplicate incubations and error bars indicate the standard deviations of the average values

Fig. 3 Profiles of sulphate consumption from Spanish phosphogypsum ( $a$ and $b$ ) and from Tunisian phosphogypsum (c and d) by the bacterial consortium WWT-1. Two different concentrations of phosphogypsum were used: $5 \mathrm{~g} \mathrm{l}^{-1}$ (a and $\mathrm{c}$ ) and $10 \mathrm{~g} \mathrm{l}^{-1}$ (b and d). Data are the average of duplicate incubations and error bars indicate the standard deviations of the average values

Fig. 4 Profile of sulphate consumption from $5 \mathrm{~g} \mathrm{l}^{-1}$ of Portuguese phosphogypsum by the bacterial consortium WWT-1 using different carbon sources: lactate, ethanol and wine wastes. Data are the average of duplicate incubations and error bars indicate the standard deviations of the average values

Fig. 5 Composition of the two bacterial communities (PG and WWT-1) in the end of the study of biotransformation of Portuguese phosphogypsum $\left(10 \mathrm{~g} \mathrm{l}^{-1}\right)$. The 17 most abundant bacteria in all samples identified by Next Generation Sequencing and the corresponding Operational Taxonomic Units (OUTs) are showed. Each bacterium has both a broad group name (Phylum) and a specific name (Genus). If no genus name can be assigned, the best assignment is shown. The \% of relative abundance was determined according to the number of reads of each taxonomic group and the total number of reads of each sample (21278 for inoculum PG and 27680 for inoculum WWT-1).

Fig. 6 Effect of PG as sulphate source on the 13 most abundant bacteria present in the two consortia (PG and WWT-1): initial bacterial community structure (initial) and bacterial community structure in the end of the study of biotransformation of Portuguese phosphogypsum $\left(10 \mathrm{~g}^{-1}\right)$ (final). 


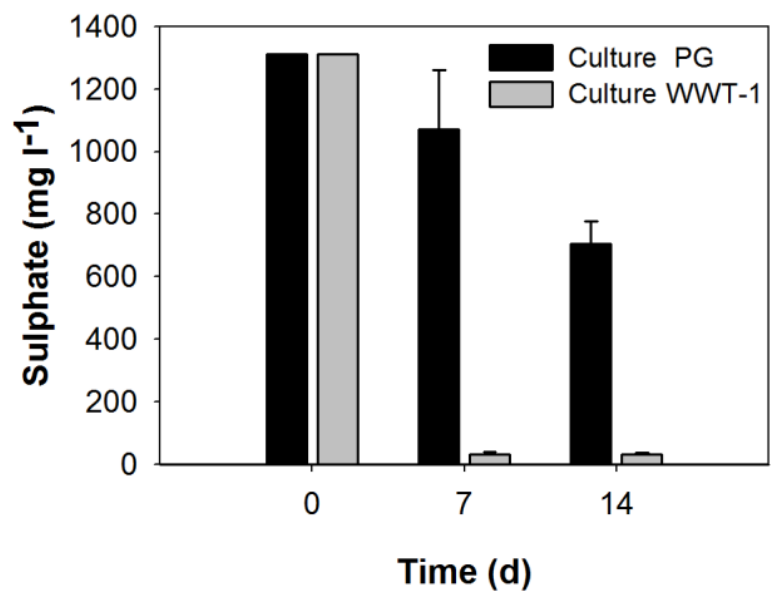

Figure 1 


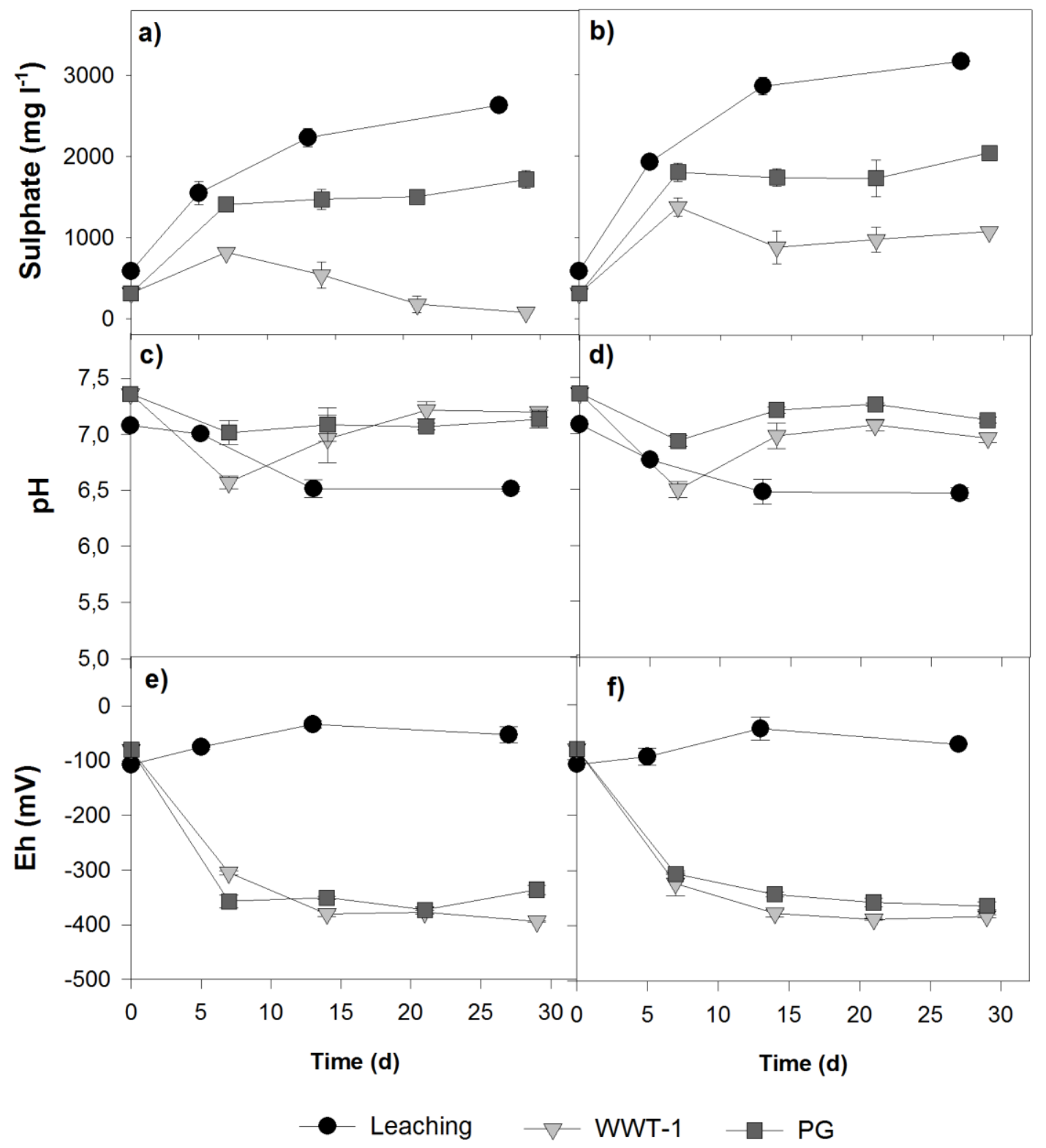

Figure 2 


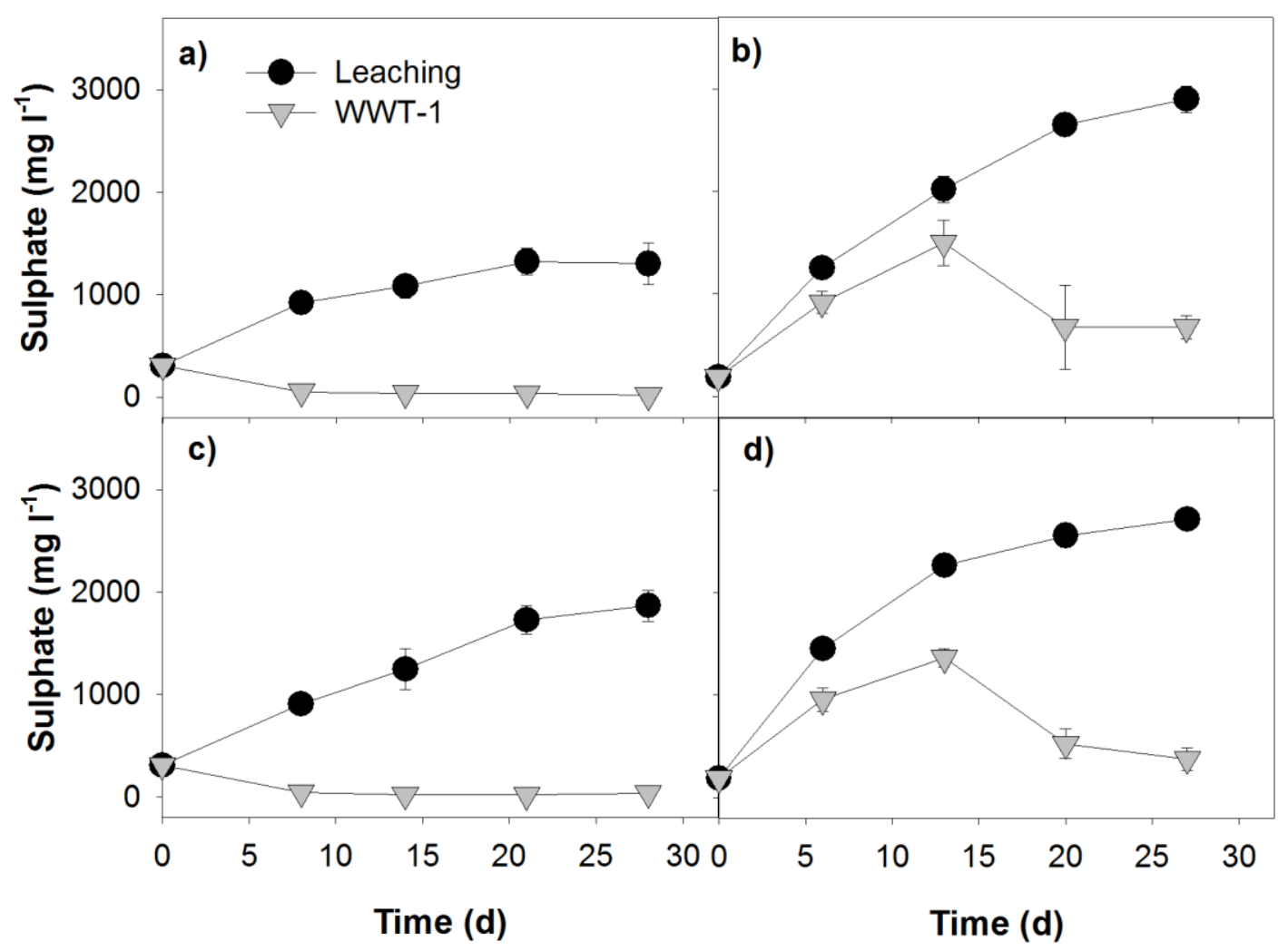

Figure 3

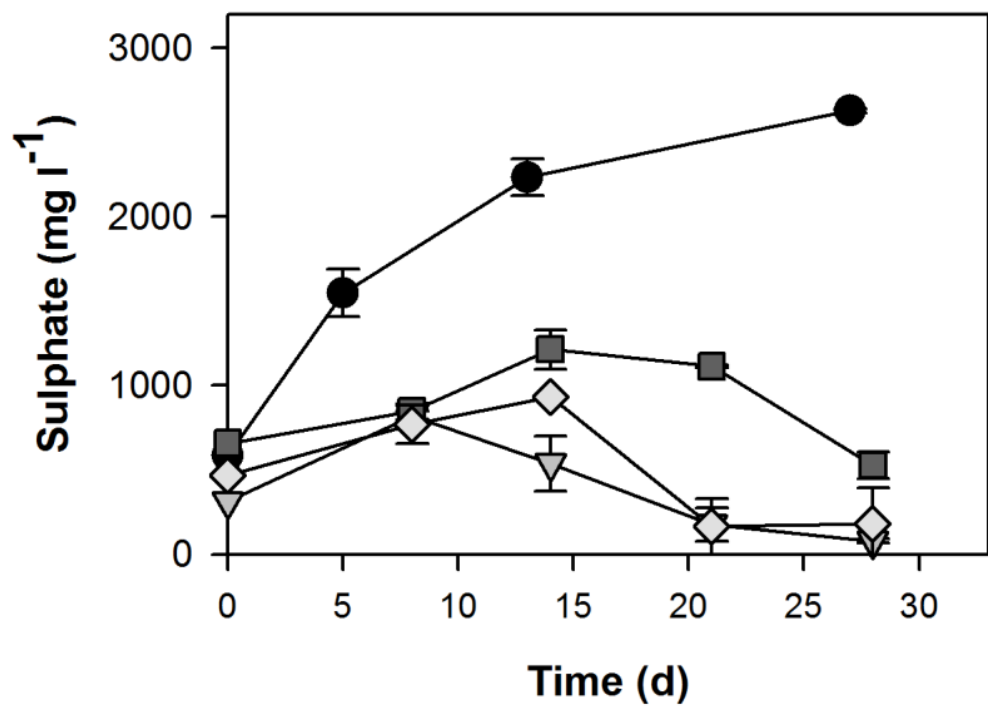

$\neg-$ Leaching $\rightarrow \nabla-$ Lactate $\neg \square$ Ethanol $\diamond-$ Wine wastes

Figure 4 


\begin{tabular}{lll|c|c}
\hline & Bacteria affiliation & OTU & \multicolumn{2}{c}{ \% Relative abundance } \\
\hline Phylum & Genus or the best assignment & 1 & PG & WWT-1 \\
\hline Proteobacteria & Sulfurospirillum & 1 & 0 & 7.9 \\
Bacteroidetes & Family Porphyromonadaceae & 6 & 0.1 & 10.9 \\
Proteobacteria & Desulfovibrio & $5 ; 7 ; 44 ; 140 ; 149 ; 161 ; 241 ; 267$ & 0 & 6.3 \\
\hline Firmicutes & Clostridium & $3 ; 15 ; 16 ; 20 ; 98 ; 111 ; 203$ & 1.8 & 11.8 \\
\hline Firmicutes & Desulfosporosinus & $17 ; 30$ & 66.2 & 0 \\
\hline Bacteroidetes & Bacteroides & $11 ; 87 ; 93 ; 220 ; 249$ & 0.1 & 0.6 \\
\hline Firmicutes & Family Clostridiaceae & 26 & 18.9 & 0 \\
Proteobacteria & Acetobacter & 2 & 0 & 0.7 \\
\hline Proteobacteria & Desulfomicrobium & $8 ; 43$ & 0 & 3.3 \\
\hline Proteobacteria & Arcobacter & 10 & 0 & 15.4 \\
Firmicutes & Order clostridiales & $25 ; 182$ & 0 & 20.2 \\
Spirochaetes & Sphaerochaeta & $29 ; 79 ; 234$ & 0 & 0.4 \\
Firmicutes & Sedimentibacter & $9 ; 218$ & 0 & 0.3 \\
\hline Fusobacteria & Cetobacterium & 34 & 0 & 6.3 \\
\hline Proteobacteria & Desulfobulbus & 22 & 0 & 4.3 \\
\hline Bacteroidetes & & 41 & 0 & 0.3 \\
\hline Firmicutes & Family Lachnospiraceae & 45 & 3.1 & 0 \\
\hline
\end{tabular}

Figure 5

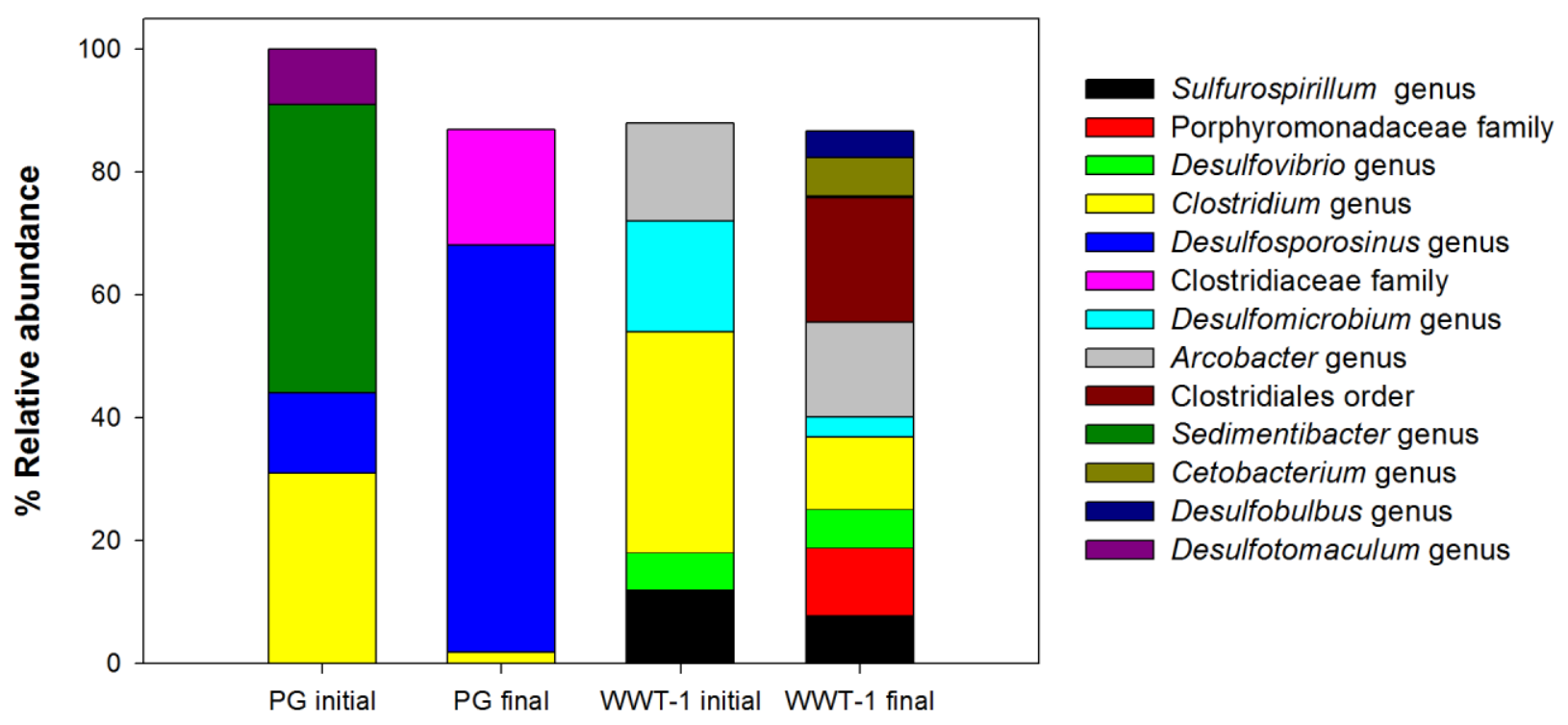

Communities

Figure 6 